UDK 372.881.161.1

DOI 10.22363/2312-8011-2017-14-1-28-42

\title{
RUSSIAN IN GHANA AND STUDENTS’ COMMON ERRORS
}

\author{
Y. Dzyadyk \\ University of Ghana \\ P.O. Box 207, Accra, Legon, Ghana
}

The motivation for language learning is influenced by political, social and cultural influence. The Russian language was introduced to the academic curriculum at the University of Ghana several decades ago. To understand advantages and disadvantages of Russian learning, it is necessary to reveal what is behind the language policy in Ghana.

In this paper, we consider how language structures are used in the Russian language, and how local languages affect it. By means of the influence of both English language and local languages, we observe common errors that appear in students' speech and papers.

Key words: motivation, Ghana, Russia, common errors

You can never understand one language until you understand at least two.

Geoffrey Willans

\section{INTRODUCTION}

Language is a social phenomenon. It can go through the processes of development if only a certain society exists. Language cannot exist beyond the society. Being socialized, language follows the time. Language cannot be stigmatized. It functions in a new way under new conditions.

The motivation for language learning is influenced by socio-cultural and political factors of a country the language of which is presented in a particular society. The stronger economy of the country the more motivation learners have. It can be proved on the basis of the French language under Napoleon Bonaparte, Spanish language in the period of powerful Spanish Fleet, English language of the British monarchy [1].

We will look at the language situation in Ghana, particularly on the basis of Russian as a foreign language.

The Russian language was introduced to the academic curriculum in Ghana several decades ago. In order to unravel both advantages and disadvantages of Russian learning, it is necessary to reveal what is behind the foreign-language policy in Ghana. The Soviet leadership did well inviting students to the Soviet schools providing free education for them. With the collapse of the Soviet Union, the situation changed drastically on the education level. In recent years, the cooperation between Ghana and modern Russia as a successor of the former Soviet Union, has been brought to a new level and become more fruitful. 
The use of a certain language envisages specific social behavior and interaction among members of a society. Language is a symbol of behavior in a society. The relation between a language and a society is based on the abundance of both linguistic and extra-linguistic factors. There exist both close language interconnection and mutual influence in multilingual space. This phenomenon is clearly seen in those multilingual societies, in which an official language co-exists with local languages and is influenced by them. Multilingualism became a norm rather than an exception [2].

Primary socialization of a child in Ghana starts from the very first days after a child is born. The family members begin communicating with a baby in the language typical of the family. They use Twi, Ga, Fanti, Hausa or any other local languages. When a child grows, the enclosed area is not narrow any more, and the child has an access to other ethnic groups. While being in touch with friends from other language groups, the child is involved in the process of unstoppable march of "language bombarding" (of course, in positive meaning of the word) [3].

If we consider the variety of languages spoken, we come to an understanding that multilingualism has more advantages than disadvantages. Multilingual users get many benefits [4]. Better job prospects, a cognitive boost, protection against mental disorders are some of them. Research shows that they can view the world in different ways depending on the specific language they are operating in. Brain receives a positive impulse. Mental flexibility occurs more often, and mental activity has a certain protective effect. A speaker has to switch sounds, cultural concepts, grammatical structures (Thomas Bak, a neurologist at the University of Edinburgh, Scotland; Brian Gold, a neuroscientist at the University of Kentucky, Lexington). Ageing processes are also delayed in multilinguals. This category of people tend to make more rational decisions in a second/third language [4-8]. Some activities were organized by the Cambridge Bilingualism Network in order to address the following questions:

- How does multilingualism affect relations between individuals and their communities?

- What are the cognitive advantages of multilingualism?

- How far can current linguistic theories account for code-switching? (Prof. Wendy Ayres-Bennett, Dr. Dora Alexopoulu, Dr. Napoleon Katsos).

In accordance with the curriculum, the University of Ghana offers blocs of courses to first-year students, among which a foreign language appears. Besides, the number of academic hours is not enough, and it makes the learning process difficult. That is why many of students drop the language course at Level 200. Some of the students do not have any desire or motivation to continue learning any foreign languages, since the University "decides" for them in terms of choosing major courses. But motivated students have an opportunity to do a foreign language as a major course beginning with Level 300. Finally, they participate in a year-abroad programme.

The students are offered the Course Outlines where the language policy, objects, learning outcomes are described to make the cooperation between students and lecturers more fruitful.

\section{ABOUT THE COURSE}

Course Code and Title: RUSS 431: Advanced Language Proficiency Credits: 1 
Lecture Period(s) and Venue: Wednesday, 09:30-10:20, Multimedia Room MLD

Prerequistes: RUSS 342 Russian Language Skills, RUSS 344 Contemporary Russia: Politics and Society, RUSS 348 Translation From and into Russian

Course Instructor(s)

Name: Mr. Yuriy Dzyadyk

Office location: DF/MLD 013

Office hours: Tuesday: 12:30 - 13:30; Wednesday: 14:00 - 15:00

E-mail: ydzyadyk@ug.edu.gh

Teaching Assistant: Larbi Osumanu, Rashida

\section{Introduction/Subject Overview or Course Description:}

The course will focus on a good command of Russian. It involves a comprehensive review of Russian grammar at an advanced level with emphasis on comprehension, reading, writing and oral skills.

The course occupies 1 credit hour of the total number of credit hours and it will be purely language based. Dr. G.N. Adam will hold another two-credit part of the course.

\section{Course Objective/Goals:}

The attainment of a high level of language proficiency in comprehension, translations practice and oral skills.

Students should understand complicated Russian texts, be ready to discuss problems raised. They have to use complex grammatical structures.

\section{Learning Outcomes:}

The course will start with the revision of aspects of Russian grammar and vocabulary. The study of new materials will be done through using "Знакомимся с русскими традициями и жизнью россиян" and "Yeralash" textbooks since they enable students to practice out-of-class language skills. Monthly movie shows will help students to get acquainted with the culture behind the language and will help the students to cope with difficulties of Russian environment alive. At the end of every month students will have to present projects on selected topics.

\section{Course Delivery (optional):}

This is the language part of the course.

\section{Plagiarism policy}

Students are to present authentic papers. If plagiarism (materials copied from another student) is detected, both the original and the copied work will be cancelled. No mark will be awarded. Internet and materials from other resources should be only used if they are necessary. In those cases the source of information should be given.

$\begin{array}{ll}\text { Assessment and Grading } & \\ \text { Mid-Semester Test/Interim Assessment } & 5 \% \\ \text { Presentation and Class Participation } & 5 \% \\ \text { Final Exam } & 20 \%\end{array}$

\section{Grading Scale:}

One credit is for the linguistic aspect of the course. There will be a written examination.

Ten percent of the given course will be determined by continuous assessment and class attendance, as well as mid-semester test. Apart from weekly assessment of take-home 
assignment, vocabulary and grammar short tests will be held. Students should be active in class. They must attend classes and come on time.

Twenty percent is reserved for the end-of-semester oral examinations.

\section{Reading List/Required Text}

1. Н.В. Баско. Знакомимся с русскими традициями и жизнью россиян. М., 2010.

2. Манова Н.Д., Палоши И., Чайбок-Тверефу И. и др. Смотрим веселый Ералаш, 2014.

3. Вохмина, Л.Л. Русский класс: Учебник русского языка для иностранных учащихся. М.: Русский язык. 2011.

4. Ryasanova-Clarke, L., Wade, T. The Russian Language Today. Routledge, 1999.

5. Voynova, E.I., Matveeva, V.M., Averyanova, G.N., Bratus', B.V. Uchebnik Russkogo Yazyka Dlya Inostrannikh Studentov Filologov. M.: Russkiy Yazyk, 1986.

\section{Other Information:}

Students have to be active in class, take part in class discussions. They are also advised to study on their own. They have to practice materials learnt in class with their groupmates. They also need to work systematically to bring their knowledge to a higher level. The students can listen to radio programmes, watch the Russian TV programmes as well as movies, read Russian fiction and poetry at least 50 minutes daily. They have to be aware of events going on both in Russia and the Russian language environment, study Russian culture and traditions through various resources available.

Course Delivery Plan/Schedule includes the following topics (Level 400):

\begin{tabular}{|c|c|c|c|c|}
\hline Week & Date & Lecture \# & Topic & $\begin{array}{c}\text { Comments } \\
\text { (Homework assignment) }\end{array}$ \\
\hline 1 & 19.08.15 & 1 & $\begin{array}{l}\text { Motherland and foreign countries Food, } \\
\text { clothes }\end{array}$ & Ex.8,9 p.12 \\
\hline 2 & 26.08 .15 & 1 & National character Shopping & Ex.8,9 p.25 \\
\hline 3 & 02.09 .15 & 1 & Important events in our lives Etiquette & Ex. 8,9 p.38-39 \\
\hline 4 & 09.09 .15 & 1 & $\begin{array}{l}\text { Russians and family ties Relations between } \\
\text { schoolmates }\end{array}$ & Ex.8,9p.54 \\
\hline 5 & 16.09 .15 & 1 & $\begin{array}{l}\text { Russian cuisine Moscow underground train } \\
\text { system }\end{array}$ & Ex. 8,9 p.68 \\
\hline 6 & 23.09 .15 & 1 & Private and state property Emergencies & Ex.8p.82 \\
\hline 7 & 30.09 .15 & 1 & $\begin{array}{l}\text { A visit to a Russian friend Russia and activities } \\
\text { of Russians }\end{array}$ & Ex. 8,9 p.93 \\
\hline 8 & 07.10 .15 & 1 & Friendship and Russians Sport & Ex. 8,9 p. 108 \\
\hline 9 & 14.10 .15 & 1 & Labour and Russians Relations in a family & Ex. 8 p.119 \\
\hline 10 & 21.10 .15 & 1 & Education in Russia At a hospital & Ex.8p.133 \\
\hline 11 & 28.10 .15 & 1 & $\begin{array}{l}\text { Public transport in Russia Children and par- } \\
\text { ents }\end{array}$ & Ex.8,9p.149 \\
\hline 12 & 04.11 .15 & 1 & Trade in Russia Technology and Russia & Ex.8p.160-161 \\
\hline 13 & 11.11 .15 & 1 & Leisure and Russians & Ex.8p.173-174 \\
\hline
\end{tabular}

(C) 2016 University of Ghana

In the process of teaching, we notice mistakes on phonetic, lexical and grammatical levels. Russian is a Slavic language of Eastern Europe. The typical mistakes help to set 
the peculiarities, to select the methods of teaching, to direct the teaching/learning process in the right way.

Difficulties appear from the first class since the Cyrillic alphabet is used in the Russian language. The letters can be divided into four main groups:

\section{Group 1.}

Letters similar to English letters in form and pronunciation:

Aa [a], Oo [o], Ee [e], M [m], Kk [k], T [t].

\section{Group 2.}

Letters similar to English letters in form but different in pronunciation:

Yy [u], Bb [v], H [n], Pp [r], Cc [s].

\section{Group 3.}

Letters corresponding letters in Greek:

Гг [g], Дд [d], Лл [1], Пп [p], Фф [f], Хx [x].

\section{Group 4.}

Remaining letters:

Бб [b], Зз [z], Ёё [yo], Жж [3], Ии [i:], Йй [j], Цц [ts], Чч [tg], Шш [J], [ftg], ь [‘], ы [у], Ээ [е], Юю [уu], Яя [уа].

On phonetic level, some sounds are not pronounced properly. The Twi closed phoneme [o] resembles [u]. It causes incorrect lexeme usage. The word «стол» [stol] 'a table' is pronounced with vowel sound $[\mathrm{u}]$ which finds another word «стул» [stul] meaning 'a chair'.

Combinations of $-s k$ which is replaced by $-k \mathrm{~s}$ and $-f l$ which is replaced by $-f r$ create another problem in middle and initial positions: Москва-Моксва, Флор-Фрол [MaskvaMaksva, Flor-Frol].

The incorrect use of stress leads to confusion when we deal with homographs. The meaning depends on the correct stress: Уже-ужЕ [Uzhe-uzhE] (more narrow-already), зАмок-замОк [zAmok-zamOk] (palace-lock), городА-гОрода [garadA-gOrada (cities [plural noun]-of a city [genitive case of singular noun)]. In unstressed positions phoneme $-o$ is pronounced [a], while in stressed positions $-[0]$. Therefore, we present Russian pronunciation in English transcribed examples.

On lexical level, when addressing a lecturer or senior officers students use Sir/Madam or $M r . / M s$ which is not typical of Russian though these forms exist господuн/госпожа [gaspadin/gaspazha] but they are used in addressing foreigners rather than locals: гocnoдин Брайтон/госпожса Брайтон [Mr./Ms Brighton].

Three-component name is used in the Russian language (first name, middle name[father's name with a certain suffix], last name): Иван Романович Соколов/ Мария Ивановна Соколова [Ivan Ramanovich Sakalov (m)/Mariya Ivanavna Sakalova (f)]. Accordingly, middle names can be divided into groups:

Male names ending in a consonant [b, l, m, n, r, s, t] (б, л, м, н, p, c, т): Иванович/ Ивановна [Ivanavich/Ivanavna] (father's name is Ivan [Иван]). Masculine forms are used with a final form -ovich, feminine -ovna (spelling is used with phoneme -o).

Male names ending in the combination -іу (ий): Васильевич/Васильевна [Vasilyevich/Vasilyevna] (father's name is Vasiliy [Василий]. In these forms the stem of a father's name is taken into account Vasil- (Bacuл-) and soft sign with a final form -'yevich (m)/-'yevna (f) are added. 
Male names ending in -еу(ей): Андреевич/Андреевна [Andreyevich/Andreyevna] (father's name is Andrey [Андрей]). The stem of a father's name Andre- (Андре-) and a final form -yevich (m)/-yevna (f) are used.

Male name Pavel [Павел] has the following structure: Павлович/Павловна [Pavlavich/Pavlavna]. The last but one vowel $-e$ is dropped before final forms -ovich (m)/-ovna (f) (spelling is used with phoneme -o).

The lexeme "please' is borrowed from local language through English into Russian, even though it is out of use: Do you have a book? - No, please. У тебя есть книга? Нет, пожалуйста. [U tebya yest kniga? - Net, pazhalusta.]

The following English nouns have similar equivalents in the Russian language: a planetпланета, а problem-проблема, а тіпите-минута, а sесоnd-секунда. When comparing with the English version, students are deceived because they use the same form as it appears in the English language. Even though, the forms are similar but they are not identical. Russian nouns of this group have ending [a] which shows that the gender of the nouns is feminine. Using English form states the masculine gender which is incorrect.

Approximate lexemes lead to typical mistakes, too. In the following questions

Какое домашнее задание у Вас будет на завтра? [ [Kakoye damashnyee zadaniye u Vas budet na zaftra?] (1)

Что у Вас будет на завтрак? [Shto u Vas budet na zaftrak?] (2)

we can notice the similar forms at the end of the questions. They are used with the same prepositions. Unfortunately, the words are not synonyms and have different meaning. In sentence (1) we deal with adverb, while sentence (2) has noun in its structure.

Sentence (1): What homework assignment will you have for tomorrow?

Sentence (2): What will you have for breakfast?

Sentence extension can help to work out the meaning of the lexemes:

Что у Вас будет завтра на завтрак? [Shto u Vas budet zaftra na zaftrak?] (3)

Sentence (3): What will you have for breakfast tomorrow?

Seeing two approximate forms within the sentence boundaries, students might be alert that it is impossible to use the same lexemes: obviously, these should be if not different parts of speech, then different nouns.

The Russian language possesses two forms of the pronoun you: official and unofficial. It is easy to understand the phenomenon for those students who did French course before, since forms $t u /$ vous exist in the French language. Russian form $m b l$ [ty] is used to address friends or family members that are in close relations, while $в b l[\mathrm{vy}]$ is used when addressing older people, teachers, officers and also two or more people. For English-speaking students it is difficult to differentiate between these forms at the beginning. They often make mistakes. It should be taken into account that it is not polite, or rather rude, if a person uses wrong forms in wrong situations in Russia, e.g. when addressing a lecturer, a student uses $m b l$ [ty]-form instead of $8 b l$ [vy].

It often happens that foreign students mix up $-u / b l$, or $u / \breve{u}$; it leads to typical mistakes because the letters are not identical, and the words might have quite different meanings: пытаться [pytatsa] (to try), питаться [pitatsa] (to eat); мой друг [moy drug] (my friend [singular]), мои друзья [mai druzya] (my friends [plural]).

We found out that time clusters are used in incorrect way. If the minute has not reached figure 6 , the time is indicated by means of 1 ) a cardinal numeral in the nominative case; 
2) the word ' 1 минута, 2-4 минуты, 5-20 минут'; 3) the genitive case of the ordinal numeral denoting the next full hour: 8:10 - десять минут девятого [desyat" minut devyatava], 1:15 - четверть второго [chetvert' vtarova], 4:02 - начало пятого [nachala pyatava] (several minutes past ...).

If the minute hand points to figure 6 , the time is indicated by the word 'половина' [palavina] followed by the genitive case of the ordinal numeral denoting the next full hour: 11:30 - половина двенадцатого [palavina dvenatsatava].

If the minute hand has passed figure 6 , the time is indicated by 1) the preposition ' $б е з$ ' [bes]; 2) the genitive case of the cardinal numeral denoting the minutes; 3 ) the nominative case of the cardinal numeral denoting the next full hour: 7:40 - без двадцати восемь [bes dvatsati vosem'] [8].

While learning the foreign language, local way of thinking prevails. Polysemantic units cause confusion for learners. Difficulties occur in translating realia, and often word-forword interpretation creates the comic effect: закончить школу/университет с золотой медалью/красным дипломом [zakonchit'shkolu s zalatoy medalyu/krasnym diplomam] (to finish secondary school/graduate from the university with honours). Literal translation creates difficulties since it does not make any sense: word combinations are translated "golden medal and red diploma".

On grammatical level, prepositions of location and direction, three genders (masculine, feminine, neuter) and six cases, as well as declension of nouns, cause difficulties.

Unlike English, the Russian verbs denoting location or direction use the same preposition in post position: It affects the noun since direction requires the accusative case while location requires the prepositional case: Он пошел в школу. Он в школе. Compare: He went to school (direction). He is at school (location). By means of prepositions, the forms are identified.

Normally, gender in Russian is identified by means of the ending: consonants, and some words with soft sign $-b$ (causes palatalization) are typical of masculine nouns: брат [brat] (brother), словарь [slavar'] (dictionary); ending -a, -я [a, ya] and soft sign feminine: сестра [sistra] (sister), дочь [doch'] (daughter); -о, -е [o, уе] - neuter: окно [akno] (window), mope [morye] (sea).

Some nouns ending in $-a$, $-я$ belong to masculine gender: папа, дядя, дедушка, юноша. They have feminine endings; therefore, they are declined as feminine nouns but when possessive pronouns or adjectives are added, their endings reflect masculine nouns: мой дядя, хороший папа, красивый юноша [moy dyadya, haroshyy papa, krasivyy yunasha] (my uncle, nice daddy, handsome lad). When applying translation, we can be sure that these nouns cannot be feminine. Compare endings of feminine nouns in opposite pairs: моя тетя, хорошая мама, красивая девушка [maya tyotya, haroshaya mama, krasivaya devushka] (my aunt, nice mommy, pretty young lady).

Soft sign makes palatalization occur in words, while hard sign $-\bar{\sigma}$ helps to separate syllables where it is necessary to avoid joint parts between the consonant and vowel sounds: подъехать [pad-ye-hat'] (approach). Without hard sign, the word will sound [pa-de-hat'] which is not typical of the Russian language; sometimes hard sign separates prefixes from the root of the word. Prefixes add new meaning to the words: ехать [yehat'] (to go using transport), поехать [payehat'] (to leave), подъехать [padyehat'] (to approach), приехать [priyehat'] (to arrive), доехать [dayehat'] (to reach). Some words can exist in both forms 
with different meaning: сесть [s'est'/siest'] (to have sat down), съесть [s-yest'] (to have eaten).

A typical mistake occurs in a pair 'ферма/фирма' [ferma/firma] (a farm/a firm). In a lexeme 'ферма', [e] is pronounced [3:]. It makes students use a wrong version if they translate it as 'a firm/a company'.

The Russian verb system has a complex structure based on tenses, two conjugations and aspects. For native speakers it is easy to identify the declension by using verbs, third person plural. The correct ending depends on the conjugation: $-u$ - or $-e-$. If a verb has ending $-y m /-ю m ~[u t, y u t]$ in third person plural, the verb belongs to Conjugation I and verb endings in all other persons possess -e (-ешь, -ет, -ем, ете); if ending is $-a m /-я m$ [at yat], it shows Conjugation II and verb endings in all other persons contain $-u$ element (-uшь, -um, -uм, -ume). It influences verb endings in all other persons and number. The wrong ending in third person plural will sound clumsy. But for foreign students this technique does not work because foreigners do not have intuitive perception of the language at the primary stage of learning. Sometimes, any form seems correct. The form 'сидю' [sidyu] (to sit) like some other verb forms is wrongly used even by native speakers, especially from rural areas. The correct version is 'сижу' [sizhu].

Double negation is used in Russian unlike in the English language: Я никого не видел [Ya nikavo ni videl. Compare: I saw no one].

Adverbial modifiers of time in the Russian language borrowed English punctuation: In spring 1992, we moved to Tomsk. Весной 1992 (года), мы переехали в Томск. Vesnoy 1992 goda, my pereyehali v Tomsk. The adverbial modifier of time cannot be separated by means of comma in the Russian sentence: Мы переехали в Томск весной 1992 года.

Here we offer the samples of tests that are used in the University of Ghana in Lexicology (Test 1), Russian Language Skills (Test 2.1, Test 2.2). If the tests are passed, students change the language level to a higher one and they are ready to participate in a yearabroad programme:

\section{Test 1}

1. Which of the following words are used in the plural only?

Братья, будни, трактора, берега, прятки, овощи, города, каникулы, листья, макароны, сутки, магазины, шашки, друзья, дрожжи, чернила, ворота, ученики, брюки, апельсины.

2. Find out the Gender of the following words:

Гость, радость, кофе, путь, егоза, насекомое, юла, домище, самоучка, бремя, судья, семя, дитя, дядя, подмастерье, парнишка, здоровье, семья, дедушка, самоучитель.

3. Identify animate and inanimate nouns:

Открыватель, животное, молодежь, староста, лес, фрукт, покойник, учение, русалка, леший, человечество, громкоговоритель, мертвец, птица, платье, институт, кошка, спорт, инженер, множитель.

4. Find words which are reflective adjectives:

Домашний, большой, музыкальный, честный, дорогой, кирпичный, хлебный, злой, деревянный, глупый, автобусный, умный, добрый, книжный, хороший, университетский, красивый, манговый, белый, школьный. 
5. Explain the lexical and grammatical peculiarities of the underlined words:

1) Какие технические масла ты обычно покупаешь?

2) Разве это недоступные высоты?

3) Сосед по комнате все берет без спросу.

4) Студенты достигли хороших результатов.

5) Хор запел.

6. Use the words in brackets in the appropriate case:

1) Мы приехали домой ... (самая короткая дорога).

2) Мальчик хочет стать ... (физик).

3) Я удивляюсь его ... (поведение).

4) Другу очень нравится рубашка ... (белый цвет).

5) Это очень хороший подход к ... (решение) вопроса.

6) Она покраснела от ... (стыд).

7) Сестра уехала в Лондон ... (лето).

8) Он купил дом благодаря ... (помощь) отца.

9) Она не придет на собрание из-за ... (дождь).

10) Студент занимался ... (вся ночь).

11) Я знаю молодого человека, ... (работающий) на почте.

12) Кофи получил деньги от сестры, ... (живущий) в Мадине.

13) Все это случилось при ... (Нкрума).

14) Есть хочется, можно попросить ... (хлеб).

15) Говорят, что сегодня ... (времена) будет дождь в городе.

The practical course of the Russian language includes two parts of testing: Grammar (Test 2.1) and Orals (Test 2.2):

\section{Test 2.1}

1. Answer the following questions using words instead of figures in brackets and the right preposition (10 marks):

1) Когда у вас начинаются лекции в университете? (9:00)

2) Когда в университете кончаются занятия? (14:00)

3) Когда начинается фильм? (16:30)

4) Когда начинает работать библиотека? (10:00)

5) Когда вы обычно обедаете? (12:15)

6) Когда вы встаете? (7:30)

7) Когда по радио передают новости? (13:00)

8) Когда брат кончает работать? (18:45)

9) Когда дети ложатся спать? (21:50)

10) Когда начинают работать магазины? (8:00)

2. Answer the following questions using the words in brackets in the required case. Write out the whole sentences (10 marks):

1) По какому парку гуляли дети? (большой парк)

2) В каком городе вы живете? (красивый город)

3) В каком море хорошо плавать? (теплое Черное море)

4) С кем они разговаривали? (молодой переводчик)

5) Какой мультфильм показывали в воскресенье? (новый интересный мультфильм) 
6) Какой костюм он купил? (вечерний костюм)

7) Какого человека вы встретили? (тихий приветливый человек)

8) Какое яблоко взял ребенок? (большое красное яблоко)

9) Какой фильм надо смотреть? (хороший фильм)

10) Около какого дома построили магазин? (высокий дом)

3. Answer the questions using words in brackets in the appropriate case. Write out the whole sentences (10 marks):

1) В какой тетради вы пишете? (толстая синяя тетрадь)

2) В какой школе учится ее сын? (новая средняя школа)

3) На какой фабрике работает девушка? (большая современная фабрика)

4) Какую погоду вы любите? (теплая весенняя погода)

5) Какую рубашку он наденет завтра? (летняя светлая рубашка)

6) Какую газету он читает? (свежая утренняя газета)

7) Кому отец купил подарок? (младшая дочь)

8) По какой улице едут машины? (новая широкая улица)

9) Кем гордится профессор? (талантливая ученица)

10) В какой вазе стояли цветы? (новая ваза)

4. Complete the sentences using the verbs ехать/ездить; идти/ходить in the past tense. Write out the whole sentences (10 marks):

1) Вчера мы ... к знакомым, которые живут далеко от нашего дома.

2) Туда мы ... на метро, а обратно на такси.

3) Летом мои друзья ... на юг на поезде.

4) Вчера мы долго ... по лесу пешком.

5) Туристы ... на экскурсию в старинный русский город.

6) Целый день они ... по музеям города.

7) Недавно студенты ... в деревню.

8) Сначала они ... на машине, потом на автобусе.

9) А потом они ... пешком.

10) Когда они ..., они пели веселые песни.

\section{Translate into Russian (10 marks):}

1) Tom is going to the doctor's.

2) My friend received a letter from his friend.

3) They went to the shop in the morning.

4) Zhenya is at his friend's now.

5) Apples are more delicious than pears.

\section{Test 2.2}

Read carefully the text:

\section{TEXT 1}

\section{Русские традиции}

Традиции - это не только то, что отличает один народ от другого, но и то, что объединяет самых разных людей. Семейные традиции русского народа - наиболее интересная часть истории и культуры Российского государства, которая знакомит нас с опытом наших предков. Семейные традиции России никогда не обходились без генеалогии: было стыдно не знать родословную, а самым обидным прозвищем считалось «Иван, не помнящий родства». Когда появились фотоап- 
параты, люди стали составлять, а потом и хранить семейные альбомы. Этот обычай успешно дошел и до наших дней - наверное, у большинства имеются старые альбомы с фотокарточками дорогих сердцу родных. Давней русской традицией можно назвать и передачу вещей, принадлежащих далеким (и не очень) предкам, своим потомкам. Например, прабабушкина шкатулка или прадедушкины часы семейные реликвии, которые хранятся долгие годы в уголке дома. История вещей становится историей народа.

Существует также прекрасный обычай называть ребенка в честь кого-нибудь из членов семьи (есть так называемые «семейные имена»). Когда малыш рождается, он тут же получает часть имени рода по «прозванию» своего отца. Отчество отличает человека от тезки, проливает свет на родство (сын-отец) и выражает почтение. Семейные традиции, примеры которых в настоящее время практически не найти, это старинные профессиональные династии (то есть когда все члены семьи занимались каким-то одним видом деятельности). Известны целые династии потомственных пекарей, артистов. И, конечно же, самым любимыми являются семейные праздники, поскольку все еще сильны в нас традиции древнерусского застолья.

На Руси к приему гостей готовились, убирая не только дом, но и двор. Всех входящих гостей встречали хлебом-солью, затем выходила хозяйка, кланялась всем, а гости отвечали ей тем же. Потом все садились за общий стол, пели песни, а хозяева угощали всех кашей, щи, рыбой, ягодами, медом. Стоит отметить, что для сервировки стола использовались скатерти, полотенца и посуда, хранимые в сундуках и буфетах для торжественных случаев. Любопытно, что многие современные хозяйки соблюдают некоторые обычаи из старых времен [9].

\section{Vocabulary:}

Народ - nation

Отличать - differentiate

Объединять - unite

Государство - state

Родословная - family tree

Обычай, традиция - tradition

Предки - ancestors

Почтение - respect

Шкатулка - small box

Пекарь - baker

Хозяйка - mistress

Скатерть - table cloth

Праздники - holidays

\section{TEXT 2}

\section{Обучение иностранцев в России}

Система обучения в России имеет хорошую традицию и всегда была открыта для талантливой молодёжи. Людей, которые учились в России, всегда ценили за образование и знания. Большой приток иностранных студентов был в советское время. Те, которые получили образование в России и полюбили её, готовы по- 
могать престижу российской высшей школы. В современном мире авторитет государств определяется их интеллектуальным потенциалом, развитием науки и высшей школы. Сегодня функционируют 45 российских центров науки и культуры в 40 странах. Обучение на курсах русского языка может стать первым шагом к получению иностранцами высшего образования в России. В свою очередь, Россия гордится теми, кому она помогла получить путевку в профессиональную жизнь. Во время жизни и учебы в России иностранные студенты знакомятся с российской историей и культурой, приобретают друзей на всю жизнь, а заканчивая учёбу и возвращаясь домой, большинство из них становятся посланниками России в самых отдаленных уголках планеты.

Для сотен тысяч людей языком общения стал русский язык - язык Пушкина и Лермонтова, Толстого и Достоевского, Чехова и Бунина, язык сказок и песен. У большинства выпускников вместе с языком выработан русский менталитет и, встречаясь где-то в Европе, или на другом континенте, они всегда очень рады друг другу, как будто встретились братья. Укрепление позиций русского языка и русской культуры за рубежом вызывает все больший интерес мировой общественности к России, ее истории и сегодняшней жизни, политике и экономике. Студенты самых разных стран, живя в России, накапливают опыт других студентов, приехавших из стран с различным уровнем развития, а главное - учатся жить вместе в мире и дружбе с разными народами. Это интернациональное воспитание вместе с качественной профессиональной подготовкой позволяет иностранным студентам после окончания обучения в России возвратиться на Родину и на деле доказывать высокий уровень российской высшей школы. И, прежде всего, бывшие студенты российских вузов являются в своих странах тем классом, который формирует готовность местных элит, деловых кругов, культурной общественности сотрудничать с российскими организациями и Россией. Много выпускников поддерживают постоянную связь с Россией, давшей им образование [10].

\section{Vocabulary:}

Талантливая молодежь - talented youth

Приток - flow

Развитие науки и обучения / высшей школы — development of science and higher education

Ценить и гордиться - appreciate and be proud

Сотрудничать, жить в мире и дружбе - cooperate, live in peace and friendship

Выпускник - graduate student

Посланник - messenger

Деловые круги - business elite

Связь, отношения - relations

Общественность - society

Менталитет - mentality

After reading the text, the students are asked to answer some questions and discuss the topics related to the main ideas in the texts that students read. 


\section{SUMMING UP}

Common errors determine the peculiarities of teaching Russian, help to choose the appropriate methods, modify the structure of classes. Teaching Russian in Ghana takes an important place in popularization of Russian culture and traditions.

(C) Yuriy Dzyadyk, 2017

\section{REFERENCES}

[1] Dzyadyk Yurij, Chajbok-Tverefu Il'diko Prepodavanie russkogo yazyka v angloyazychnoj srede Gany [Teaching Russian in English-speaking context of Ghana]. Russkij yazyk za rubezhom. № 1. 2016. P. 124-128.

[2] Dzyadik Yu. Anglijs'kij pidzhin Nigeriï ta Gani: istoriya ta suchasnist'. Visnik L'vivs'kogo universitetu. Seriya mizhnarodnih vidnosin. 2012. Vip. 30.

[3] Dako, K., Yitah, H., 2012, Pidgin, 'Broken' English and 'Othering' in Ghanaian Literature. Legon Journal of Humanities. Spec. Edit. URL: http://klub-drug.ru/deti/semejnye-tradicii-vrossii- cennosti-russia.html (data obrashcheniya 05.12.2016).

[4] Bialystok, E., 2011, Reshaping the Mind: The Benefits of Bilingualism. Canadian Journal of Experimental Psychology, Vol. 65, No. 4, pp. 229-235.

[5] Bialystok, E., Craik, F.I.M., 2010, Cognitive and Linguistic Processing in the Bilingual Mind. The Current Directions in Psychological Science, pp. 19-23.

[6] Bialystok, E., Craik, F.I.M., Luk, G., 2012, Bilingualism: Consequences for Brain and Mind. Trends in Cognitive Science, Vol. 16, Issue 4, pp. 240-250.

[7] Lam, E., Rosario-Ramos, E., 2009, Multilingual Literacies in Transnational Digitally-Mediated Contexts: An Exploratory Study Of Immigrant Teens in the U.S. Language and Education, 23(2), pp. 171-190.

[8] Maddux, W.W., Adam, H., Galinsky, A.D., 2010, When in Rome, Learn Why The Romans Do What They Do: How Multicultural Learning Experiences Facilitate Creativity. Personality and Social Psychology Bulletin, 36, pp. 731-741.

[9] Paradowski, M.B. The Benefits of Multilingualism. URL: http://www.multilingualliving. com/2010/05/01/the-benefits-of-multilingualism-full-article/, Access: April 25, 2016.

[10] Vasilenko E., Lamm EH. Russkij - samostoyatel'no [Self-learned Russian]. M.: Russkij yazyk, 1986. P. 274-275. URL: http://ukc-sputnik.ru/obrazovanie_v_rossii (data obrashcheniya 07.05.2016).

Article history:

Received: 03.11.2016

Accepted: 06.01.2017

Moderator: V.P. Sinyachkin

For citation:

Dzyadyk Yu. (2017). Russian in Ghana and Students' common errors. RUDN Journal of Language Education and Translingual Practices, 14 (1), 28-42.

Bio:

Dzyadyk Yuriy is language tutor of the Department of Foreign Languages, University Of Ghana. E-mail: ydzyadyk@ug.edu.gh 


\title{
КУРС РУССКОГО ЯЗЫКА В УНИВЕРСИТЕТЕ ГАНЫ И ТИПИЧНЫЕ ОШИБКИ СТУДЕНТОВ
}

\author{
Ю. Дзядык \\ Университет Ганы \\ Почтовый ящик 207, Аккра, Легон, Гана
}

Общество, культурное наследие нации влияют на изучение иностранных языков. Русский язык был введен в программу Университета Ганы несколько десятилетий назад. Чтобы говорить о преимуществах и недостатках изучения русского языка в Гане, необходимо понимать языковую политику правительства Ганы на протяжении всего этого периода.

Цель настоящей работы - показать, как общие языковые структуры влияют на изучение русского языка и до какой степени происходит влияние официального английского и местных языков на преподавание русского языка как иностранного. Типичные ошибки были обнаружены в процессе тестирования студентов.

Ключевые слова: мотивация, Гана, Россия, типичные ошибки

\section{СПИСОК ЛИТЕРАТУРЫ}

[1] Дзядык Юрий, Чайбок-Тверефу Ильдико. Преподавание русского языка в англоязычной среде Ганы // Русский язык за рубежом. № 1/2016. С. 124-128.

[2] Дзядик Ю. Англійський піджин Нігерії та Гани: історія та сучасність // Вісник Львівського університету. Серія міжнародних відносин. 2012. Вип. 30.

Электронный ресурс: URL: http://klub-drug.ru/deti/semejnye-tradicii-v-rossii-cennosti-russia. html (дата обращения 05.12.2016).

[3] Dako, K., Yitah, H., 2012, Pidgin, 'Broken' English and 'Othering' in Ghanaian Literature. Legon Journal of Humanities. Spec. Edit.

[4] Bialystok, E., 2011, Reshaping the Mind: The Benefits of Bilingualism. Canadian Journal of Experimental Psychology, Vol. 65, No. 4, pp. 229-235.

[5] Bialystok, E., Craik, F.I.M., 2010, Cognitive and Linguistic Processing in the Bilingual Mind. The Current Directions in Psychological Science, pp. 19-23.

[6] Bialystok, E., Craik, F.I.M., Luk, G., 2012, Bilingualism: Consequences for Brain and Mind. Trends in Cognitive Science, Vol. 16, Issue 4, pp. 240-250.

[7] Lam, E., Rosario-Ramos, E., 2009, Multilingual Literacies in Transnational Digitally-Mediated Contexts: An Exploratory Study Of Immigrant Teens in the U.S. Language and Education, 23(2), pp. 171-190.

[8] Maddux, W.W., Adam, H., Galinsky, A.D., 2010, When in Rome, Learn Why The Romans Do What They Do: How Multicultural Learning Experiences Facilitate Creativity. Personality and Social Psychology Bulletin, 36, pp. 731-741.

[9] Paradowski, M.B. The Benefits of Multilingualism. URL: http://www.multilingualliving. com/2010/05/01/the-benefits-of-multilingualism-full-article/, Access: April 25, 2016.

[10] Василенко Е., Ламм Э. Русский - самостоятельно. М.: Русский язык, 1986. С. 274-275. Электронный ресурс: URL: http://ukc-sputnik.ru/obrazovanie_v_rossii (дата обращения 07.05.2016).

\section{История статьи:}

Поступила в редакцию: 03.11.2016

Принята к публикации: 06.01.2017

Модератор: В.П. Синячкин 
Для цитирования:

Дзядык Ю. Русский язык в Гане и типичные ошибки студентов // Вестник Российского университета дружбы народов. Серия: Вопросы образования: языки и специальность. 2017. Т. 14. № 1. C. 28-42.

Сведения об авторе:

Юрий Дзядык, преподаватель русского языка кафедры иностранных языков Университета Ганы. E-mail: ydzyadyk@ug.edu.gh 